\title{
WOMEN'S FEMORAL MASS CONTENT CORRELATES TO MUSCLE STRENGTH INDEPENDENTLY OF LEAN BODY MASS
}

\author{
A MASSA FEMORAL DAS MULHERES RELACIONA-SE COM A FORÇA MUSCULAR INDEPENDENTEMENTE \\ DAMASSA MAGRA
}

\author{
LA MASA FEMORAL DE LAS MUJERES SERELACIONA CON LA FUERZA MUSCULAR, INDEPENDIENTE \\ DE LAMASAMAGRA
}

Luciana Duarte Pimenta ${ }^{1}$

(Physical Education Professional)

Danilo Alexandre Massini²

(Physical Education Professional)

Daniel Dos Santos

(Physical Education Professional)

Leandro Oliveira Da Cruz Siqueira²

(Physical Education Professional)

Andrei Sancassani ${ }^{2}$

(Physical Education Professional)

Luiz Gustavo Almeida Dos Santos ${ }^{3}$

(Physical Education Professional)

Bianca Rosa Guimarães ${ }^{4}$

(Physiotherapist)

Cassiano Merussi Neiva ${ }^{3}$ (Physical Education Professional)

Dalton Muller Pessôa Filho ${ }^{3}$

(Physical Education Professional)

1. Universidade de Franca (Unifran), Health Promotion Graduate

Program, Franca, SP, Brazil.

2. Universidade Estadual Paulista

(UNESP), Instituto de Biociências,

Human Development and

Technologies Graduate Program, Rio Claro, SP, Brazil.

3. Universidade Estadual Paulista (UNESP), Faculdade de Ciências,

Bauru, SP, Brazil.

4. Universidade José do Rosário Vellano (Unifenas), Divinópolis, MG, Brazil.

\section{Correspondence:}

Dalton Muller Pessôa Filho.

Av. Engo Luiz Edmundo Carrijo

Coube, s/n, Bauru, SP,

Brazil. 17033-360.

dmpf@fc.unesp.br

\begin{abstract}
Introduction: There is limited consensus regarding the recommendation of the most effective form of exercise for bone integrity, despite the fact that weight training exercise promotes an increase in muscle mass and strength as recurrent responses. However, strength variations in women do not depend on muscle mass development as they do in men, but strength enhancement has shown the potential to alter bone mineral content (BMC) for both sexes. Objective: This study analyzed the potential of muscle strength, as well as that of whole-body and regional body composition, to associate femoral BMC in young women. Methods: Fifteen female college students (aged $24.9 \pm 7.2$ years) were assessed for regional and whole-body composition using dual-energy X-ray absorptiometry (DXA). Maximum muscle strength was assessed by the one-repetition maximum (1RM) test in the following exercises: bench press (BP), lat pulldown (LP), knee flexion (KF), knee extension (KE) and $45^{\circ}$ leg press (45LP). Linear regression analyzed BMC relationships with regional composition and $1 \mathrm{RM}$ values. Dispersion and error measures ( $R^{2}$ aj and $S E E$ ), were tested, defining $p \leq 0.05$. Results: Among body composition variables, only total lean body mass was associated with femoral $B M C$ values ( $R^{2} a j=0.37, S E E=21.3 \mathrm{~g}$ ). Regarding strength values, 1RM presented determination potential on femoral BMC in the CE exercise $\left(R^{2} a j=0.46, S E E=21.3 \mathrm{~g}\right)$. Conclusions: Muscle strength aptitude in exercises for femoral regions is relevant to the femoral mineralization status, having associative potential that is similar to and independent of whole-body lean mass. Therefore, training routines to increase muscle strength in the femoral region are recommended. In addition, increasing muscle strength in different parts of the body may augment bone remodeling stimulus, since it can effectively alter total whole-body lean mass. Level of Evidence ll; Development of diagnostic criteria in consecutive patients (with universally applied reference "gold" standard).
\end{abstract}

Keywords: Body composition; Muscle strength; Women; Young adult; Bone density; Femur.

\section{RESUMO}

Introdução: Há pouco consenso em relação à recomendação sobre o exercício mais efetivo para a integridade óssea, apesar de o exercício com peso apresentar como respostas recorrentes o aumento da força e da massa muscular. Contudo, entre mulheres as variações da força não dependem do desenvolvimento da massa muscular, tanto quanto em homens, mas o aumento da força tem evidenciado potencial para alterar o conteúdo mineral ósseo (BMC) em ambos os sexos. Objetivos: O presente estudo analisou o potencial da força muscular, assim como da composição regional e corporal, ao associar o BMC do fêmur entre as mulheres jovens. Métodos: Quinze universitárias (24,9 7,2 anos) foram avaliadas quanto à composição regional e corporal por meio de absorciometria por duplo feixe de raios-X (DXA). A força muscular máxima foi avaliada por uma repetição máxima (1RM) nos exercícios de supino-reto (SR), puxada-alta (PA), flexão do joelho (FJ), extensão do joelho (EJ) e leg press $45^{\circ}$ (LP45). A regressão linear analisou as relações de BMC com a composição regional e os valores de 1RM. Foram testadas medidas de dispersão e erro ( $R^{2} a j$ e EPE), definindo $p \leq 0,05$. Resultados: Entre as variáveis da composição corporal, apenas a massa magra corporal total associou-se aos valores de BMC femoral $\left(R^{2} a j=0,37\right.$, $E P E=21,3 \mathrm{~g}$ ). Em relação aos valores de força, 1RM no exercício de CE apresentou potencial de determinação sobre o BMC femoral ( $R^{2} a j=0,46, E P E=21,3 \mathrm{~g}$ ). Conclusão: A aptidão da força muscular em exercícios para regiões próximas ao fêmur é relevante para o estado de mineralização femoral, com potencial associativo similar e independente à massa magra corporal. Recomenda-se, portanto, rotinas de treinamento para aumentar a força muscular da região próxima ao fêmur; adicionalmente, o aumento da força para diferentes regiões corporais pode potencializar o estímulo sobre a remodelação óssea, uma vez que é efetivo na alteração da massa magra corporal total. Nível de Evidência ll; Desenvolvimento de critérios diagnósticos em pacientes consecutivos (com padrão de referência "ouro" aplicado).

Descritores: Composição corporal; Força muscular; Mulheres; Adulto jovem; Densidade óssea; Fêmur.

\section{RESUMEN}

Introducción: Hay poco consenso con relación a la recomendación sobre el ejercicio más efectivo para la integridad ósea, a pesar de que el ejercicio con peso presenta como respuestas recurrentes el aumento de la fuerza y de la masa muscular. Sin embargo, entre mujeres las variaciones de la fuerza no dependen del desarrollo de la masa muscular, 
tanto como en hombres, sino que el aumento de la fuerza ha evidenciado potencial para alterar el contenido mineral óseo (BMC) en ambos sexos. Objetivos: El presente estudio analizó el potencial de la fuerza muscular, así como de la composición regional y corporal, al asociar el BMC del fémur entre las mujeres jóvenes. Métodos: Quince universitarias (24,9 $\pm 7,2$ años) fueron evaluadas cuanto a la composición regional y corporal por medio de absorciometría de rayos X de doble energía (DXA). La fuerza muscular máxima fue evaluada por una repetición máxima (1RM) en los ejercicios de press de banca recto (PBR), remada alta (RA), flexión de rodilla (FR), extensión de rodilla (ER) y leg press $45^{\circ}(L P 45)$. La regresión lineal analizó las relaciones de BMC con la composición regional y los valores de 1RM. Fueron probadas medidas de dispersión y error ( $R^{2}$ aj y EEE), definiendo $p \leq 0,05$. Resultados: Entre las variables de la composición corporal, sólo la masa magra corporal total se asoció a los valores de BMC femoral ( $R^{2} a j=0,37, E E E=21,3 \mathrm{~g}$ ). Con relación a los valores de fuerza, 1 RM en el ejercicio de CE presentó potencial de determinación sobre el BMC femoral ( $R^{2} a j=0,46, E E E=21,3 \mathrm{~g}$ ). Conclusión: La aptitud de la fuerza muscular en ejercicios para regiones próximas al fémur es relevante para el estado de mineralización femoral, con potencial asociativo similar e independiente a la masa magra corporal. Se recomiendan, por lo tanto, rutinas de entrenamiento para aumentar la fuerza muscular de la región próxima al fémur; adicionalmente, el aumento de la fuerza para diferentes regiones corporales puede potencializar el estímulo sobre la remodelación ósea, dado que es efectivo en la alteración de la masa magra corporal total. Nivel de Evidencia Il; Desarrollo de criterios diagnósticos en pacientes consecutivos (con patrón de referencia "oro" aplicado).

Descriptores: Composición corporal; Fuerza muscular; Mujeres; Adulto joven; Densidad ósea; Fémur.

\section{INTRODUCTION}

Observing the association between aging, physical activity level, bone mineral mass (BMC) and lean mass (LM), Proctor et al. ${ }^{1}$ stated the tendency of physical activity reduction from 20 to 80 years old ranging about 34-38\% for women, simultaneously to the reduction of LM (18-17\%) and BMC (16$30 \%)$. These authors even postulated about positive correlations between $L M$ development and BMC increase in this population ( $r=0.74)$. Other studies also showed correlations between LM and BMC, or bone mineral density (BMD), when analyzing populations of women of different age groups and bone health status. For example, for elderly non-obese women with and with no osteoporosis, both LM and fat mass (FM) tend to influence whole-body $B M D\left(R^{2}=0.38, p<0.001\right)$ and $B M C\left(R^{2}=0.54, p<0.001\right)^{2}$. Thus, the relevance of whole-body FM is emphasized for people having low amount of $L M$, which is aligned with the observation that young women tend to maintain healthy BMC/BMD levels with the increase of $\mathrm{LM}^{2,3}$

In addition, for Xiang et al. ${ }^{4}$, the LM has positive effect (19\% and 48\%) to $B M C$ and $B M D$ variations in whole-body, spine and hip, but also to the increased physical activity level (0.112 to 0.759). According to these authors, after a physical activity program affecting BMC/BMD from 22\% to $33 \%$, variations in whole-body FM play a negative role (-0.524 to -0.940), which corroborates the results of Reid's study ${ }^{5}$ about thee increased association between LM and BMC/BMD with physical activity. However, the importance of $L M$ reduces as exercise is practiced regularly, especially among younger women (premenopausal age range), highlighting the effect of neuromuscular conditioning as the preponderant mechanical factor in regulation of osteogenic activity ${ }^{6}$. Even, physical conditioning also evidence the role of FM at normal levels on the secretion of estrogen as a humoral factor in the regulation of osteoblast activity ${ }^{7}$. Thus, the susceptibility of postmenopausal women to the risk of osteoporosis there is support to the low levels of physical activity.

However, different factors are responsible for altering the relationship between whole-body LM and FM with BMC/BMD, such as differences in body size and hormonal secretion among women in different periods of life, which may obscure the biological importance of each body indexes for bone density. In other hands, muscle strength increase modulate bone and muscle metabolism, and also the ability of bone tissue to respond to mechanical stress, especially among young and adults of both sexes ${ }^{2,8-10}$. Therefore, resistance training (with load intensity between $50-80 \%$ of maximal repetition, 1RM) has demonstrated recurrent effectiveness in the regulation of BMC/BMD, especially in long-term planning (i.e.: > 12 months), either by increasing BMC/BMD (up to 3.8\%) or preventing significant reductions of $\mathrm{BMC} / \mathrm{BMD}(\sim 2.5 \%)$ among sedentary individuals after menopause. ${ }^{11-15}$

Nevertheless, not all studies showed BMC/BMD changes from resistance training intervention, despite LM and muscle strength changes are often evident. For example, for Ryan et al. ${ }^{16}$ resistance training promotes improvements in muscle strength for young men and women ( $<30$ years) and elderly (> 60 years), as well as, LM (for all, with exception older women) and whole-body BMC, but not whole-body BMD, being the response greater among young men. Also for Liang et al. ${ }^{17}$ resistance training was not effective to promotes regional changes of BMD and LM among adult women (20-35 years), despite the increase in muscle strength for lower limbs (55\%). This ambiguity of effect on regional and whole-body BMC/ BMD has been observe for different ages and both sexes.

Thus, if the relationship between muscle strength and BMC/BMD is suppose from the assumption of mechanical stress stimulus on the bone tissue ${ }^{8}$, then can be assumed for young individuals that the variations in muscular strength tend to distinguish bone structures regarding BMC/ BMD status, independently of LM differences. Thus, the contribution of the present work was to add evidence of the direct, independent and causal relationship between muscular strength and femoral BMC status among young female. The aim was to support the viability of muscular strength conditioning to analyze femoral BMC.

\section{METHOD}

15 women took part in the sample, with the following features: $24.9 \pm 7.2$ years old, $162.4 \pm 5.0 \mathrm{~cm}$ tall and weighing $59.1 \pm 6.2 \mathrm{~kg}$. All of them met the following criteria: female, aging 18-35 years old, Caucasian, with no prior experience in weight training and were not obese. They received instructions on how to proceed and signed a Free and Informed Consent. This study was approved by the Local University Ethics Committee (protocol: 70076317.1.0000.5398).

\section{Meansurement}

The DXA method (Hologic ${ }^{\oplus}$ model, QDR Wi ${ }^{\circledR}$ Discovery) was used to obtain body total and regional composition. The software of body composition (Hologic APEX ${ }^{\circledR}$ ) assessed lean mass and fat-free mass (lean 
mass (LM), bone mineral content (BMC)) for upper and lower limbs in both sides of the body, giving references of regional composition (fat mass (FM), fat-free mass (FFM) and total mass) of upper (UL) and lower limbs (LL), trunk ( $T$ ) and whole body (WB). The equipment was calibrate following the manufacturer's recommendation and an expert technician carried out the process. The evaluation procedures followed the suggestions of Nana et al. ${ }^{18}$.

\section{Strength measurement}

1RM tests were perform using the following machines: (a) bench press (BP), (b) front pulley (FP), (c) leg-curl (LC), (d) knee extension (KE), and ( $\mathrm{f}$ ) leg press $45^{\circ}(\mathrm{LP} 45)$. All these tests were carried out after a 15-minute warm-up (static stretching, riding a bicycle or jogging slowly). The test 1RM protocol follow the recommendations of Baechle and Earle ${ }^{19}$ : (1) a specific warm-up with low loads and without failure; (2) initial attempt established according to age and body weight; (3) the participants performed three attempts, with 3-minute rest, and load increasing/decreasing 1,1 to 4,5 kg, according to the first attempt. The heaviest weight ( $\mathrm{kg}$ ) lift successfully represented a 1RM reference value. The 1RM test was confirmed three times using 1RM from first test, which percentages $(90,95,100,105$ and $110 \%)$ were perform randomly with a 3-minute rest between attempts. Additionally, the participants performed movements with proper technique, following Baechle and Earle. ${ }^{19}$

\section{Statistical analysis}

The variables were shown using mean, standard deviation, minimum and maximum. Linear regression, using the Stepwise method, related BMC femoral (dependent factor) with regional and whole-body composition and muscle strength of UL (BP and FP) and LL (LC, KE and LP45). Variability and dispersal were test by coefficient adjusted to the sample $\left(R_{\text {adj }}^{2}\right)$ and standard error of estimate (SEE). All procedures were peform using SPSS 24 (Statistical Package for Social Sciences, Inc., USA), setting significance at $\rho \leq 0.05$.

The sampling power for associations determined considering sample size $(\mathrm{N}=15)$. Input parameters were: (a) the " $r$ " coefficient, from variance analysis, $\left(R^{2}\right)$, (b) $Z a=1.96$ for an index de of $a=0.05$, and security $\beta=$ 1.282 (c) for a sample with a minimal potency of $80 \%$ ( $\beta=0.20)$, according to the equation bellow: ${ }^{20}$

In addition to sample power, the analysis based upon magnitude inferences was applied to test the chance of a true magnitude of an effect either substantially positive or negative, and insignificant or trivial. These chances were analyzed qualitatively, according to: $<1 \%$ (quite unlikely); 1-5\% (very unlikely); 5-25\% (unlikely); 25-75\% (possibly); 75-95\% (likely); 95- $99.5 \%$ (very likely); and $>100 \%$ (quite likely). This procedure ensures that, after repeating the exercise several times, sampling distribution of $z=0,5$ In $((1+r) /(1-r))$ will roughly tend to normality with a $1 /(n-3)$ variation. ${ }^{21}$

\section{RESULTS}

Among the individuals, \%FT was $32.7 \pm 6.6 \%$. The whole-body LM and FT values were $37.5 \pm 2.7 \mathrm{~kg}$ and $19.6 \pm 5.6 \mathrm{~kg}$, respectively. The observed femoral BMC values were 156.5 $\pm 29.0 \mathrm{~g}$ (variation: 108.0-203.6 g), and whole-body BMC was of 1925.6 $240.4 \mathrm{~g}$ (variation: 1359.6-2248.4 g). Table 1 presents others values of whole-body and regional composition. Pearson's coefficients between BMC and LM-T ( $r=0.61, p \leq 0.05), U L(r=0.52, p \leq 0.05)$, $L L(r=0.62, p \leq 0.05)$ and WB $(r=0.65, p \leq 0.01)$. Among these relationships, only LM-WB identified as an influent variable on femoral BMC, in spite of $L M-T$ and $L M-L L$ showed close coefficients. The deterministic relationship between whole-body lean mass and femoral BMC is shown in Figure 1 (Panel A), with $\mathrm{R}_{\text {adj }}=0.37$ and sampling power (=75.7\%) non-satisfactory, but the effect was considered to be "likely" to be found in other populations. Figure 1 (Panel B) indicates that the evaluation of LM-WB is able to explain the femoral BMC having an difference of 3.5\%.
Table 2 presents muscle strength values obtained in 1RM test. Pearson's coefficients observed between muscle strength with femoral BMC can also be find in Table 2. Muscle strength for exercises for lower and upper limbs showed correlations with satisfactory statistic levels with femoral BMC. Therefore, femoral BMC relationships to muscle strength were observe for both local (hip and knee) and remote (scapular belt and elbow) exercises from femur region.

Such local effect of muscle strength for femoral BMC highlight the level of strength of KE as an explanatory variable of femoral BMC (Figure 2: Panels $A$ and $B$ ). The $1 R M$ in KE exercise is associated to femoral BMC with $\mathrm{R}^{2}$ adj $=0.46$ and sampling power (=86.3\%), which effect is considered "quite likely" to be found in the other populations having the same characteristic (Figure 2: Panel A). From Figure 2 (Panels B), can be notice that $\mathrm{KE}$ is able to explain femoral BMC variations with error of $0.9 \%$. Even, the addition exercises with local effect (KE and LC) would increase influence power by $5 \%\left(R^{2}=0.55 ; p<0.01\right)$, and around $15 \%$ by adding exercises with remote effect ( $K E$ and $L C+B P$ and $\left.F P: R^{2}=0.65 ; p<0.05\right)$.

Table 1. Average $\pm \mathrm{DP}$ and minimum and maximum values for regional composition. $\mathrm{N}=15$.

\begin{tabular}{c|c|c|c}
\hline & $\begin{array}{c}\text { Total mass } \\
(\mathbf{k g})\end{array}$ & $\begin{array}{c}\text { Lean mass } \\
(\mathbf{k g})\end{array}$ & $\begin{array}{c}\text { Fat mass } \\
\mathbf{( k g})\end{array}$ \\
\hline \multirow{2}{*}{ Trunk } & $26.2 \pm 3.5$ & $17.9 \pm 1.2$ & $8.1 \pm 3.2$ \\
& $(22.0-34.0)$ & $(15.4-19.5)$ & $(4.3-14.9)$ \\
\hline \multirow{2}{*}{ Upper limb } & $6.1 \pm 0.9$ & $3.6 \pm 0.5$ & $2.3 \pm 0.87$ \\
& $(4.6--7.8)$ & $(2.8-4.9)$ & $(1.0-3.7)$ \\
\hline \multirow{2}{*}{ Lower limb } & $22.0 \pm 2.1$ & $12.9 \pm 1.3$ & $8.4 \pm 1.8$ \\
& $(17.8-27.4)$ & $(10.9-15.6)$ & $(5.9-12.5)$ \\
\hline
\end{tabular}

A

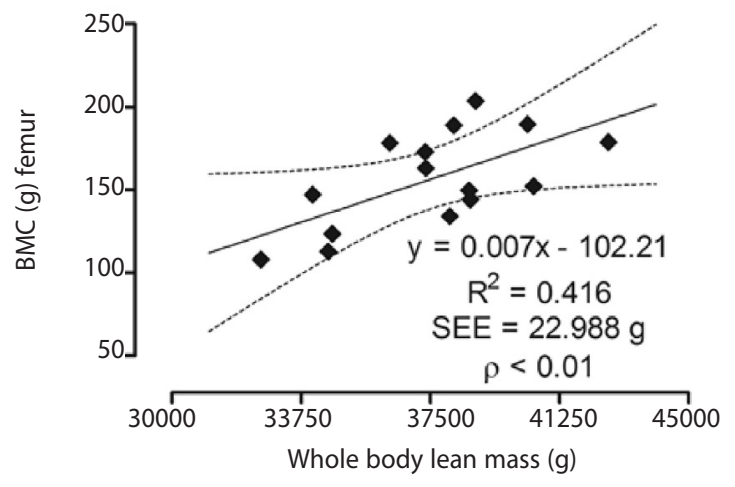

B

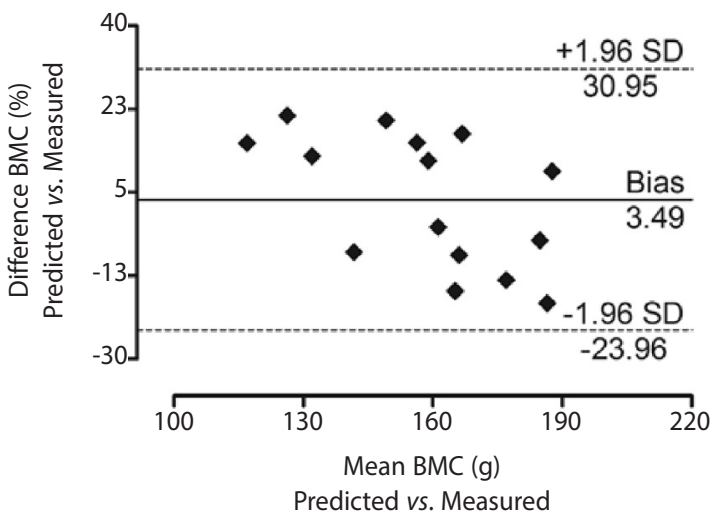

Figure 1. Dispersion and agreement analysis (Bland-Altman) between femoral BMC and LM-WB (Panels $A$ and B). N=15. 
Table 2. Average $\pm \mathrm{DP}$ and minimum and maximum values for $1 \mathrm{RM}$ strength $(\mathrm{kg})$ and Pearson's coefficients between muscle strength values and femoral BMC. N=15.

\begin{tabular}{c|c|c|c}
\hline Exercises & Averege \pm DP & $\begin{array}{c}\text { Minimum- } \\
\text { Maximum }\end{array}$ & r to BMC \\
\hline Bench Press, $\mathrm{kg}$ & $29.6 \pm 1.4$ & $20.5-40.0$ & $0.54^{*}$ \\
\hline Front Pulley, $\mathrm{kg}$ & $32.2 \pm 1.2$ & $22.0-40.0$ & $0.51^{*}$ \\
\hline Leg-Curl, kg & $42.3 \pm 10.4$ & $23.0-65.0$ & $0.64^{*}$ \\
\hline Knee Extension, $\mathrm{kg}$ & $65.3 \pm 19.6$ & $40.0-100.0$ & $0.71^{* *}$ \\
\hline Leg Press $45^{\circ}, \mathrm{kg}$ & $187.7 \pm 57.5$ & $90.0-270.0$ & $0.63^{*}$ \\
\hline significant correlation is ${ }^{*} \mathrm{p} \leq 0.05$ and ${ }^{* *} \mathrm{p} \leq 0.01$.
\end{tabular}

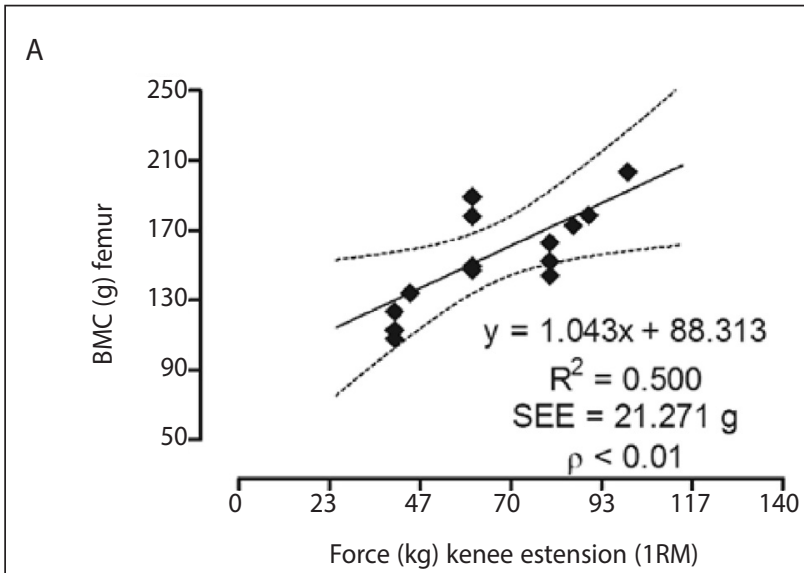

B

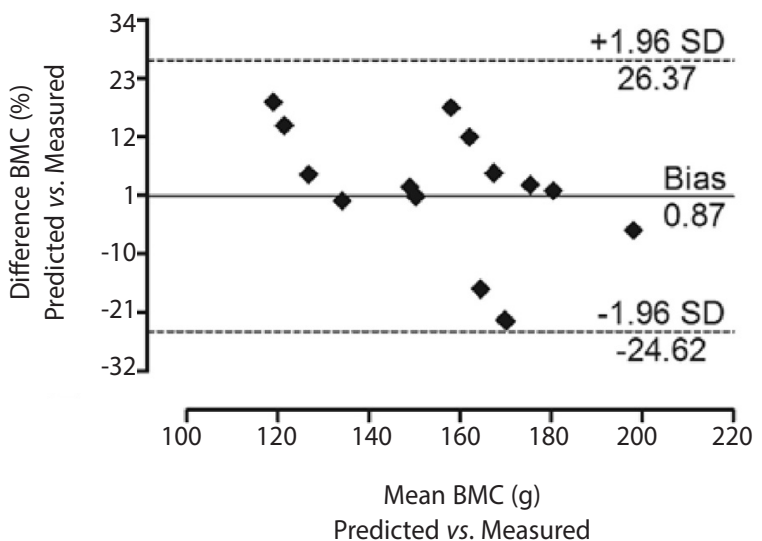

Figure 2. Dispersion and agreement analysis (Bland-Altman) between muscle strength for KE exercise and femoral BMC (Panels A and C). $N=15$.

\section{DISCUSSION}

Results have demonstrated that femoral BMC variations, in young women, are associated with both regional and body lean mass (local and remote effect of $L M$ mass as a structural stimulus), as well as associated to the muscle strength around femur region (local effect as mechanical stimulus), engaging joint movements of hip and knee combined (multi-joint) or isolated (single-joint). Therefore, this study attributes to muscle strength in exercise involving joint action, combined or isolated, of hip and knee the potential to parameterize the femoral rate of mineral loss from adulthood. This result does not minimize the importance of whole-body LM to femoral BMC, thereby confirming the presupposition of muscle contraction as the decisive factors for bone mineralization, when compared to gravitational effect of body mass (mechanical stress of support) ${ }^{5,8}$.

The predominance of support stimulus from whole-body LM on bone mineralization is well documented. In the study of Taaffe et al. ${ }^{22}$, correlations were found for older between whole-body lean mass $(r=0.41)$, whole-body fat mass ( $r=0.38)$, upper limb lean mass $(r=0.35)$, upper limb fat mass $(r=0.36)$, hand grip strength $(r=0.15)$ and knee-extensors strength $(r=0.19)$, at a high significant level $(p<0.001)$.

However, authors state for black and white women that whole-body lean mass variation is able to cause positive changes (5.7\% to 5.9\%) on femoral BMD, when compared to those (4.0\% to $4.4 \%$ ) stimulated by whole-body fat mass variations. However, these authors considered local muscle strength alterations (knee extensors) to have little relevance to femoral BMD in women, but having more relevance to BMD alterations of lower limbs (+1.9\%), both in Caucasian and black women, but with effect interacting with whole-body LM (+1.7\%) $\left(R^{2}=0.24\right)$. From the result, present study corroborated the support stimulus of whole-body LM on BMC in young women, since FM presented no association to BMC. This contrast could be related to the age group of the analyzed women, since whole-body LM tends to be effective to stimulate bone mineralization in life periods where sexual hormones would be at lower levels, like after menarche ${ }^{3}$ and in pre and post-menopausal periods ${ }^{15,23}$, given to the modulation of leptin and adiponectin by whole-body FM ${ }^{4,24-26}$.

Another effect on BMC identified, in the present study, as local tensional stimulus acting directly on femur (muscle strength for knee extensions), has been support to be decisive for osteogenesis 5,12,27,28, highlighting the ability to be improve around $5 \%$ as others muscle local actions is added (as tensional stimulus of knee flexors).

The effect of muscle strength on BMC, and particularly on femur, has been demonstrate by Nickols-Richardson et al. ${ }^{27}$, engaging young women performing one-sided training with high load intensity, planning for five months, had noticeable improvements in BMD for both trained segment and control, highlighting whole-body BMD increase (+0.4\% control and $+0.6 \%$ trained) and femoral ( $0.5 \%$ control and $1.2 \%$ trained). Furthermore, the study of Winter-Stone and Snow ${ }^{28}$ observed the local (lower limb) and remote (upper limb) effects on BMD for the region under analysis (lumbar vertebrae and hip) after resistance training in women during pre-menopause (35 to 45 years old). For these authors, after 12-month, both groups (a: exercises of high impact on lower limbs, and (b) exercises of high impact on lower limbs combined with weight exercise for upper limbs) showed improvements in hip density, whereas improvement in lumbar vertebrae was observed only in the group including exercises for upper limbs. This result highlights local effect specificity, but also shows that those remote to the region make the effect broader. This relationship was also demonstrated in this study, observing 15\% increase when adding the stimulus of muscle strength for trunk and upper limb (BP and FP) to the strength stimulus of lower limbs on femoral BMC.

Therefore, in accordance to Guadalupe-Grau et al. (2009), could be establish the potential of muscle strength to stimulate osteogenesis, planning with heavy load intensity or combined with impact exercises. This assumption is also supported by Zañudo et al. ${ }^{23}$ for women in preand post-menopausal and at risk of osteoporosis, showing increases in whole-body and femoral BMD ( 2\%) after training program (over 6 and 24 months) planned with exercises to stimulate the impact on bone system (jumping, vibratory platforms) and specific exercises to stimulate bone system by contractile tension of muscles (resistive training with 8 repetitions at $80 \% 1 \mathrm{RM})$.

\section{CONCLUSION}

The results of the study confirm the integrated nature of association between muscle mass and strength standards with bone mass variations, and highlight the existence of a specific tendency, in women, as to the specificity of strength effect (direct muscle action on bone region) and 
the global nature of lean mass effect (direct structural action on regions supporting body mass). Nevertheless, this specific strength effect does not discard strength development in remote regions, but, on the contrary, they can work together to increase the effect on bone mineralization. For future investigations, the interaction between mechanical and non-mechanical (metabolic or hormonal effects of systemic action) on bone mass (BMC) or bone mineral density (BMD) of adult females, emphasizing the effect of different physical activity programs and advice on healthy habits is suggest for future interventions.

All authors declare no potential conflict of interest related to this article

AUTHORS' CONTRIBUTIONS: Each author made significant individual contributions to this manuscript. DMPF (0000-0003-3975-9260)*, LDP (0000-0001-7956-894X)*, DAM (00000003-1088-0040)*, DS (0000-0002-5565-2351)*, and CMN (0000-0003-1635-3209)* were responsible for the conception of the proposal, data collection, presentation of results and literary discussion of the results observed. AS (0000-0002-6332-7823)*, LOCS (0000-0003-0585-4593)*, LGAS (0000-0002-4589-2933)* and BRG (0000-0003-3058-998X)* monitored the data processing, contributed to the review of the manuscript and conceptual base of the study, and of the final conceptual review. All authors approved the final version of the manuscript. *ORCID (Open Researcher and Contributor ID).

\section{REFERÊNCIAS}

1. Proctor DN, Melton $\sqcup$, Khosla S, Crowson CS, O'Connor MK, Riggs BL. Relative influence of physical activity, muscle mass and strength on bone density. Osteoporos Int. 2000;11(11):944-52.

2. Gnudi S, Sitta E, Fiumi N. Relationship between body composition and bone mineral density in women with and without osteoporosis: relative contribution of lean and fat mass. J Bone Miner Metab. 2007;25(5):326-32.

3. Young D, Hopper JL, Macinnis RJ, Nowson CA, Hoang NH, Wark JD. Changes in body composition as determinants of longitudinal changes in bone mineral measures in 8 to 26 -year-old female twins. Osteoporos int. 2001;12(6):506-15

4. Xiang J, Chen Y, Wang Y, Su S, Wang X, Xie B, Zhang Q, Liu M. Lean mass and fat mass as mediators of the relationship between physical activity and bone mineral density in postmenopausal women. J Womens Health (Larchmt). 2017;26(5):461-6.

5. Reid IR. Relationships among body mass, its components, and bone. Bone. 2002;31 (5):547-55.

6. Makovey J, Naganathan V, Sambrook P. Gender differences in relationships between body composition components, their distribution and bone mineral density: a cross-sectional opposite sex twin study. Osteoporos Int. 2005;16(12):1495-505.

7. Lee N, Radford-Smith GL, Forwood M, Wong J, Taaffe DR. Body composition and muscle strength as predictors of bone mineral density in Crohn's disease. J Bone Miner Metab. 2009;27(4):456-63.

8. Schoenau E. From mechanostat theory to development of the "Functional Muscle Bone-Unit". J Musculoskelet Neuronal Interact. 2005;5(3):232-8

9. Warren M, Petit MA, Hannan PJ, Schmitz KH. Strength training effects on bone mineral content and density in premenopausal women. Med Sci Sports Exerc. 2008;40(7):1282-8.

10. Bolam KA, Skinner TL, Jenkins DG, Galvão DA, Taaffe DR. The osteogenic effect of impact-loading and resistance exercise on bone mineral density in middle-aged and older men: A pilot study. Gerontology. 2015;62(1):22-32.

11. Almstedt HC, Canepa JA, Ramirez DA, Shoepe TC. Changes in bone mineral density in response to 24 weeks of resistance training in college-age men and women. J Strength Cond Res. 2011;25(4):1098-103.

12. Lang TF. The bone-muscle relationship in men and women. J osteoporos. 2011;2011:702-35

13. Mosti MP, Carlsen T, Aas E, Hoff J, Stunes AK, Syversen U. Maximal strength training improves bone mineral density and neuromuscular performance in young adult women. J Strength Cond Res. 2014;28(10):2935-45.

14. Bocalini DS, Serra AJ, dos Santos L, Murad N, Levy RF. Strength training preserves the bone mineral density of postmenopausal women without hormone replacement therapy. J Aging Health. 2009;21(3):519-27.

15. de Matos O, Lopes da Silva DJ, Martinez de Oliveira J, Castelo-Branco C. Effect of specific exercise training on bone mineral density in women with postmenopausal osteopenia or osteoporosis. Gynecol Endocrinol. 2009;25(9):616-20.
16. Ryan AS, Ivey FM, Hurlbut DE, Martel GF, Lemmer JT, Sorkin JD, et al. Regional bone mineral density after resistive training in young and older men and women. Scand J Med Sci Sports. 2004;14(1):16-23.

17. Liang MTC, Braun W, Bassin SL, Dutto D, Pontello A, Wong ND, et al. Effect of high-impact aerobics and strength training on BMD in young women aged 20-35 years. Int J Sports Med. 2011;32(02):100-8.

18. Nana A, Slater GJ, Hopkins WG, Burke LM. Techniques for Undertaking Dual-Energy X-Ray Absorptiometry Whole-Body Scans to Estimate Body Composition in Tall and/or Broad Subjects. Int I Sport Nutr Exerc Metab. 2012;22(5):313-22.

19. Baechle TR, Earle RW. Essentials of strength training and conditioning/National Strength and Conditioning Association. 3rd ed. Champaign, IL: Human Kinetics; 2008.

20. Díaz SP, Fernández SP. Determinación del tamaño muestral para calcular la significación del coeficiente de correlación lineal. Unidad de Epidemiología Clínica y Bioestadística. Complexo Hospitalario Juan Canalejo. A Coruña (España): Cad Aten Primaria. 2002;9:209-11.

21. Hopkins WG, Marshall SW, Batterham AM, Hanin J. Progressive statistics for studies in sports medicine and exercise science. Med Sci Sports Exerc. 2009;41(1):3-12.

22. Taaffe DR, Cauley JA, Danielson M, Nevitt MC, Lang TF, Bauer DC, et al. Race and sex effects on the association between muscle strength, soft tissue, and bone mineral density in healthy elders: the health, aging, and body composition study. J Bone Miner Res. 2001;16(7):1343-52.

23. Sañudo B, de Hoyo M, del Pozo-Cruz J, Carrasco L, del Pozo-Cruz B, Tejero S, et al. A systematic review of the exercise effect on bone health: the importance of assessing mechanical loading in perimenopausal and postmenopausal women. Menopause. 2017;24(10):1208-16.

24. Villareal DT, Aguirre L, Gurney AB, Waters DL, Sinacore DR, Colombo E, et al. Aerobic or resistance exercise, or both, in dieting obese older adults. New Engl J Med. 2017;376(20):1943-55.

25. Migliaccio S, Greco EA, Wannenes F, Donini LM, Lenzi A. Adipose, bone and muscle tissues as new endocrine organs: role of reciprocal regulation for osteoporosis and obesity development. Hormone Mol Biol Clin Investigation. 2014;17(1):39-51.

26. Mohiti-Ardekani J, Soleymani-Salehabadi H, Owlia MB, Mohiti A. Relationships between serum adipocyte hormones (adiponectin, leptin, resistin), bone mineral density and bone metabolic markers in osteoporosis patients. J Bone Miner Metab. 2014;32(4):400-4.

27. Nickols-Richardson SM, Miller LE, Wootten DF, RampWK, HerbertWG. Concentric and eccentric isokinetic resistance training similarly increases muscular strength, fat-free soft tissue mass, and specific bone mineral measurements in young women. Osteoporos Int. 2007:18(6):789-96.

28. Winters-Stone KM, Snow CM. Site-specific response of bone to exercise in premenopausal women. Bone. 2006;39(6):1203-9

29. Guadalupe-Grau A, Fuentes T, Guerra B, Calbet JA. Exercise and bone mass in adults. Sports med. 2009:39(6):439-68. 